\title{
PENGARUH PEMBERIAN EKSTRAK DAUN ANDALIMAN (Zanthoxylum acanthopodium DC.) TERHADAP HISTOLOGIS OVARIUM MENCIT (Mus musculus L.)
}

\author{
EFFECT OF EXTRACT ANDALIMAN LEAVES (Zanthoxylum \\ acanthopodium DC.) ON HISTOLOGICAL OVARY OF MICE (MUS \\ musculus $L$.)
}

\author{
Melvariani Syari Batubara ${ }^{*}$, Emita Sabri², dan Masitta Tanjung3
}

1,3Prodi Pendidikan Biologi, FKIP UMTS

${ }^{2}$ Departemen Biologi, FMIPA USU

Diterima : 04-05-2019; Disetujui : 16-01-2020: Diterbitkan : 10-02-2020

*Corresponding author: E-mail: melvarianisyari@um-tapsel.ac.id

\begin{abstract}
Abstrak
Penelitian tentang pengaruh pemberian ekstrak daun andaliman terhadap gambaran ovarium mencit, volume pemberian bahan uji dengan penggunaan jarum gavage secara oral sebanyak 0,1 ml/10 g bb 4 hari sebelum dan sesudah tahap estrus, menggunakan metode RAL non-faktorial yang terdiri dari kelompok kontrol dan perlakuan. Perlakuan terdiri dari faktor bahan uji dengan dosis 2500, 5000, 10000, 20000, 40000 ppm. Kandungan kimia ekstrak daun andaliman yang ditunjukkan dari hasil penelitian yaitu zat alkaloid, steroid dan saponin. Pemberian perlakuan ekstrak daun andaliman selama 9 hari terhadap data histologis berupa jumlah folikel primer, sekunder, De Graff, dan atretik mengalami perubahan yang berfluktuatif, tetapi secara statistik tidak menunjukkan perbedaan nyata antara kelompok mencit perlakuan dan kontrol, sedangkan hasil yang berbeda nyata ditunjukkan pada jumlah korpus luteum. Parameter diameter folikel primer, De Graff, dan korpus luteum cenderung mengalami perubahan yang berfluktuatif, namun secara statistik tidak menunjukkan perbedaan nyata antara kelompok mencit perlakuan dan kontrol, sedangkan diameter folikel sekunder dan atretik menunjukkan hasil yang sangat berbeda nyata. Dari hasil penelitian, pemberian ekstrak daun andaliman berpengaruh terhadap gambaran histologis ovarium mencit betina dewasa, karena mempengaruhi oogenesis dan ovulasi, tetapi berfluktuatif, kemungkinan disebabkan karena masih berupa ekstrak kasar, yang belum melakukan isolasi kandungan kimia.
\end{abstract}

Kata Kunci: : Andaliman, Ekstrak Etannol, Histologi, Mencit

\section{Abstract}

Research the effect of andaliman leaf extract on mice ovaries, volume test material using oral gavage needles as much $0.1 \mathrm{ml} / 10 \mathrm{~g}$ bb 4 days before and after estrus stage and using RAL non-factorial method consisting of control and treatment group. Treatment consisted of factor test material with dose 2500, 5000, 10000, 20000, 40000 ppm. Chemical content of andaliman leaf extract shown from results study are alkaloids, steroids and saponins. Giving treatment of andaliman leaf extract for 9 days on histological data in the number primary, secondary, De Graff, and atretic follicles experienced fluctuating changes, but statistically did not show a significant difference between treatment and control mice groups, while different results were significantly shown in the number of corpus luteum. Parameters diameter of primary follicles, De Graff, and corpus luteum tended to experience changes that fluctuated, but statistically did not show the difference between the treatment and control mice groups, while the diameter of secondary and atretic follicles showed significantly different results. From the results study, administration of andaliman leaf extract affects histological mice ovaries, because it affects oogenesis and ovulation, but fluctuates, possibly due to crude extract, which has not isolated chemical content.

Key Words: Andaliman, Ethanol Extract, Histology, Mice

How to Cite: Batubara, M.S., Sabri, E., dan Tanjung, M. (2020). Pengaruh Pemberian Ekstrak Daun Andaliman (Zanthoxylum acanthopodium DC.) Terhadap Histologis Ovarium Mencit (Mus musculus L.), BioLink: Jurnal Biologi Lingkungan, Industri dan Kesehatan, Vol.6 (2): Hal. 196-209 
Batubara, M.S., Sabri, E., dan Tanjung, M. Pengaruh Pemberian Ekstrak Daun Andaliman (Zanthoxylum acanthopodium DC.) Terhadap Histilogis Ovarium Mencit (Mus musculus L.)

\section{PENDAHULUAN}

Buah tanaman andaliman banyak digunakan sebagai bumbu masakan tradisional oleh suku Batak dan tanaman andaliman ini (Zanthoxylum acanthopodium DC.), merupakan tanaman perdu dari famili Rutaceae yang banyak dijumpai di daerah Sumatera Utara (Siregar, 2003). Tanaman andaliman ini termasuk anggota famili Rutaceae, genus

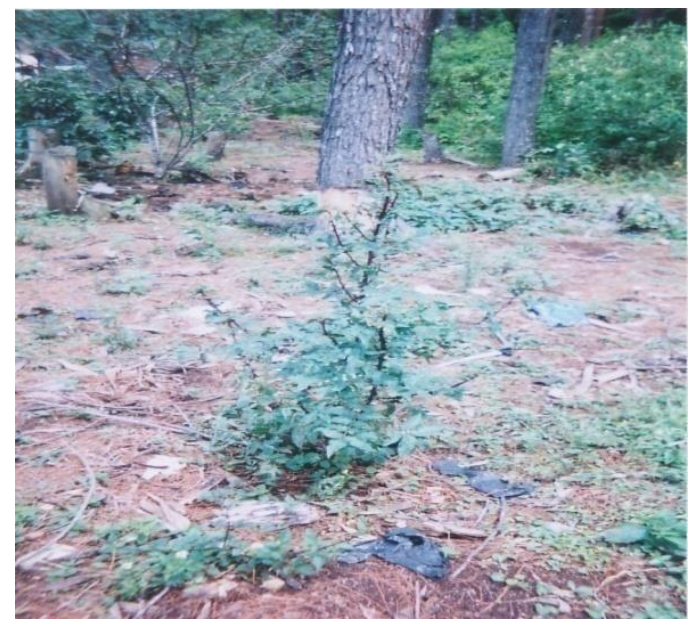

Gambar 1. Tanaman dan Daun Andaliman (Zanthoxylum acanthopodium DC.) masing mempunyai 1 biji.
Zanthoxylum, dan memiliki ciri-ciri : batangnya dan cabang tumbuhan andaliman ini berduri sejati atau aculeus, daunnya tersebar dan majemuk, daun majemuk tanaman andaliman ini menyirip beranak daun gasal, bakal buahnya apokarp atau semikarp. Satu bunga tanaman andaliman ini dapat terbentuk 14 buah bulat hijau kecil yang masing-

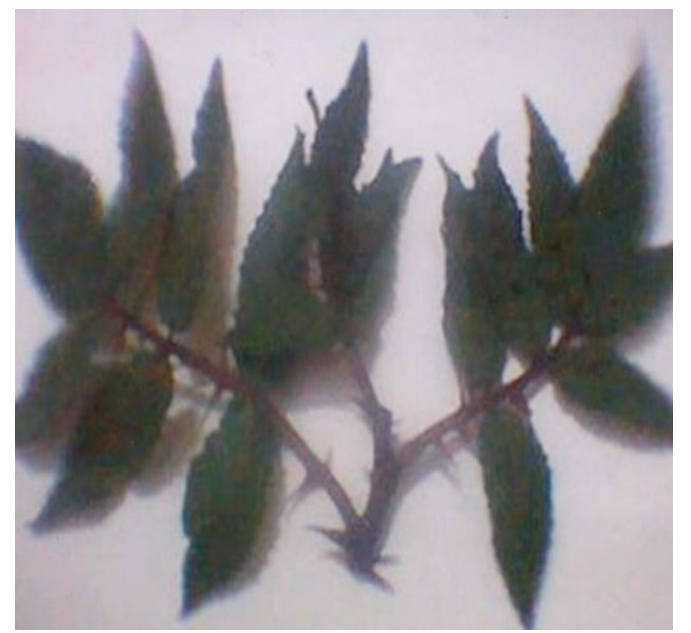

Pada umumnya tanaman andaliman ini memiliki tinggi batangnya berkisar antara 3-8 $\mathrm{m}$, batangnya dan cabang tanaman andaliman ini merah kasar beralur, juga berbulu halus dan berduri. Buah tanaman andaliman ini bulat hijau kecil, bila menggigit aroma wangi dan rasa tajam yang khas dikeluarkan pada buahnya, serta produksi air liur dapat dirangsang. Tanaman andaliman (Zanthoxylum acanthopodium DC.) ini merupakan jenis rempah-rempah dari tumbuhan liar yang dikenal oleh masyarakat suku Batak Angkola dan Mandailing, di daerah Sumatera Utara. Aroma tanaman andaliman yang khas dan menarik serta kekhasan dari tanaman andaliman ini yaitu buahnya memiliki sifat sensorik yang unik pada lidah. Efek jika dimakan buah tanaman andaliman ini dan lidah terasa kebal disebabkannya (Saragih, 2019).

Kandungan kimia bahan alam ditemukan pada berbagai jenis tumbuhan, diantaranya yang dikandung oleh tanaman menggetarkan alat pengecap ditinggalkan 
andaliman, baik pada bagian daun, bunga, buah dan batang yaitu senyawa alkaloid, flavonoid, triterpenoid, steroid, dan saponin (Hasibuan, 2017). Efek imunostimulan, aktivitas antioksidan dan antimikroorganisme dipunyai kandungan kimia berupa senyawa terpenoid tanaman andaliman ini. Hal ini memberi peluang sebagai bahan baku bagi industri pangan dan farmasi (Siregar, 2003). Untuk obat sakit gigi menggunakan buah Zanthoxylum dan batang tanaman andaliman ini sebagai sikat gigi. Bahan baku kertas menggunakan akar Zathoxylum flavum (Year, 2001).

Berdasarkan informasi dari masyarakat suku Karo telah menggunakan tanaman andaliman ini secara tradisional telah sebagai alat kontrasepsi, yang memakai bagian tanaman andaliman yaitu buahnya sebagai bumbu masak yang oleh ibu-ibu di tanah Karo mengkonsumsi secara turun-temurun sebagai antifertilitas untuk menjarangkan kehamilan. Dosis buah tanaman andaliman secara ilmiah belum dapat diketahui secara pasti. Dengan demikian penggunaan buah tanaman andaliman ini hanya berdasarkan pengamatan empiris di lapangan dan belum melakukan penelitian pengaruhnya terhadap sistem reproduksi. Pada masyarakat suku Melayu, daun tanaman andaliman ini telah lama digunakan sebagai bumbu masakan dan penghilang bau amis pada ikan dan daging. Tetapi belum ada informasi tentang penggunaan daun tanaman andaliman ini secara ilmiah.

Memilih mencit sebagai hewan uji karena ukurannya kecil, mudah disimpan dan dipelihara, serta dapat beradaptasi dengan baik di lingkungan baru. Alasan lainnya adalah karena karakteristik genetik, biologi, dan perilaku mereka semua mirip dengan manusia. Sistem reproduksi betina mencit meliputi ovarium, tuba dan uterus, vagina, serta alat kelamin betina luar. Gamet betina, yaitu ovum, melalui oogenesis dihasilkan fungsi utama sistem reproduksi betina mencit ini, kemudian menyediakan lingkungan yang cocok untuk terjadinya pembuahan oleh spermatozoa dari mencit jantan dewasa dan perkembangan fetus (Amin, 2012).

Pada potongan ovarium mencit secara umum, dapat dibedakan yaitu bagian luar adalah korteks. Korteksnya terdiri atas stroma padat selular yang mengandung folikel ovarium. Stromanya terbentuk oleh jala serat retikulin dan sel berbentuk gelendong. Sel stroma ini menyokong perkembangan teka folikel. Folikel mungkin dapat terlihat dalam berbagai tingkat perkembangan, dan penampilan korteks ovarium tergantung pada umur individu dan fase daur ovarium. Sebelum pubertas, hanya terlihat folikel primer atau primitif. Kematangan 
seks ditandai oleh adanya folikel berkembang dan hasil akhirnya (korpus luteum, folikel atretis). Sesudah mati haid (menopause) folikel menghilang dan korteks selanjutnya menjadi daerah tipis yang terdiri dari jaringan ikat fibrosa. Bagian dalam adalah medula yang menyatu dengan jaringan ikat vaskular mesovarium di hilus. Medula terdiri dari jaringan ikat fibro-elastis longgar yang mengandung pembuluh darah besar, pembuluh limfa, dan syaraf (Amin, 2012).

Selain informasi tersebut, pada masyarakat suku Dairi, daun tanaman andaliman digunakan sebagai tuba untuk mempermudah menangkap ikan, sehingga menjadi pingsan. Berdasarkan pemaparan latar belakang dan informasi yang diperoleh dari masyarakat, tanaman andaliman memiliki daya toksisitas terhadap saluran pencernaan ikan. Hal ini menjadi landasan pemikiran penulis untuk melakukan penelitian tentang "Pengaruh Pemberian Ekstrak Daun Andaliman (Zanthoxylum acanthopodium DC.) Terhadap Histologis Ovarium Mencit (Mus musculus L.) Strain DDW".

\section{METODE PENELITIAN}

Penelitian ini dilakukan di Laboratorium Struktur dan Fisiologi Hewan Departemen Biologi FMIPA USU, Medan sejak Februari sampai September
2006, menggunakan hewan uji yaitu mencit (Mus musculus L.) betina dewasa, memperolehnya dari Balai Penyidikan Pengujian Veteriner (BPPV) Dinas Peternakan Kota Medan. Menternakkan dan memelihara mencit betina dewasa tersebut di kandang hewan Departemen Biologi FMIPA USU, Medan.

Penelitian ini menggunakan bahan uji yaitu daun tanaman andaliman (Zanthoxylum acanthopodium DC.) yang memperolehnya dari desa Tanjung Beringin, Dairi, Sumatera Utara. Daun tanaman andaliman yang digunakan adalah yang masih segar dan berasal dari pohon yang belum pernah berbuah sama sekali.

\section{Pembuatan Ekstrak Daun Andaliman}

Pengeringan simplisia

membersihkan daun andaliman, dan mengering anginkan, lalu menghaluskan dengan blender. Pembuatan ekstrak andaliman : memaserasi serbuk daun andaliman dengan etanol $96 \%$ selama \pm 1 malam. Memperkolasi hasil maserasi dan simplisia sampai didapatkan cairan bening. Memekatkan hasil perkolasi dengan evaporator sampai memperoleh ekstrak yang pekat. Pembuatan sediaan suspensi : mengingat penggunaan ekstrak andaliman tidak larut dalam air, maka untuk didapatkan campuran yang 
homogen menggunakan suatu suspending agent Dimetyl Sulfoksida (DMSO) sebanyak 1,0\% atau $1 \mathrm{ml}$ dalam $100 \mathrm{ml}$ akuades.

Uji Kandungan Kimia Ekstrak Daun Andaliman

Melakukan uji pada penelitian ini digunakan metode fitokimia sebagai berikut : melakukan uji zat fenolik dengan cara ditambahkan ekstrak daun andaliman dengan $\mathrm{FeCl}_{3}$, hasil uji positif terkandung fenolik jika terbentuk larutan hitam pada sampel. Melakukan uji zat flavonoid dengan penggunaan $\mathrm{Mg}-\mathrm{HCl}$ encer dan menambahkan dengan ekstrak daun andaliman, hasil uji positif terkandung flavonoid jika terbentuk larutan berwarna merah jambu pada sampel. Melakukan uji zat alkaloid dengan penggunaan pereaksi Wagner, pereaksi Meyer, dan pereaksi Dragendorff. Menambahkan ekstrak daun andaliman dengan masing-masing pereaksi, hasil uji positif terkandung alkaloid jika terbentuk endapan berwarna putih pada sampel. Melakukan uji zat steroid dengan penggunaan $\mathrm{H}_{2} \mathrm{SO}_{4}$ (p) dan pereaksi LB (Lieberman-Burchad). Menambahkan ekstrak daun andaliman dengan masing-masing zat. Uji dengan cara ditambahkan ekstrak daun andaliman dengan $\mathrm{H}_{2} \mathrm{SO}_{4}$ (P), hasil uji positif jika terbentuk larutan berwarna merah pada sampel. Dan uji dengan cara ditambahkan ekstrak daun andaliman dengan pereaksi LB (Lieberman-Burchard), hasil uji positif jika terbentuk larutan berwarna hijau kebiruan pada sampel. Melakukan uji zat saponin dengan cara ditambahkan ekstrak daun andaliman dengan akuades, lalu mengocok sampai terbentuk buih. Hasil uji positif jika menghasilkan buih yang setelah mendiamkan selama 15 menit tetap ada dan menghasilkan tinggi buih \pm 2 $\mathrm{cm}$.

\section{Pengujian Ekstrak Daun Andaliman terhadap Hewan Uji}

Pada penelitian ini menyiapkan mencit betina dewasa yang berumur 12 minggu dengan kisaran berat badan 25-30 g. Kemudian memberi perlakuan dengan diberi minum ekstrak daun andaliman sebanyak 0,1 ml/10 g bb setiap hari dalam waktu 9 hari, yaitu 4 hari sebelum dan sesudah, serta 1 hari masa estrus, secara oral atau mencekoki dengan digunakan jarum gavage, di samping itu juga melakukan penimbangan berat badannya. Pemberian bahan uji dengan volume 0,1 $\mathrm{ml} / 10 \mathrm{~g}$ bb ini berdasarkan asumsi bahwa berat badan manusia yaitu $50 \mathrm{~kg}$ dengan dosis 1 kali pemberian $200 \mathrm{ml}$, maka untuk mencit dengan berat badan $25 \mathrm{~g}$ memberikan jumlah suspensi yaitu $0,1 \mathrm{ml} /$ hari.

Setelah masa perlakuan selesai, yaitu pada hari ke 10, membunuh mencit dari 
kelompok kontrol dan perlakuan dengan cara dislokasi leher. Meletakkan mencit yang telah mati di bak bedah dan melakukan pembedahan dengan penggunaan dissecting set untuk diangkat ovariumnya. Memasukkan ovarium ke cawan petri yang telah berisi larutan $\mathrm{NaCl}$ 0,9\%, lalu membersihkan dari lemak. Untuk melakukan pengamatan jumlah folikel ovarium dan diameter folikel ovarium dengan pembuatan preparat sayatan ovarium dengan pewarnaan Hematoxylin-Eosin dan metode parafin.

\section{Pembuatan Preparat Sayatan Ovarium}

Pembuatan preparat sayatan ovarium dilakukan dengan cara menfiksasi organ ovarium mencit terlebih dulu dengan menggunakan larutan bouin, dan dibiarkan selama 2-10 jam. Kemudian mencuci organ tersebut dengan alkohol $70 \%$ berulang kali sampai didapat cairan bening, lalu diinapkan lebih kurang satu malam dalam alkohol 70\%. Kemudian organ tersebut didehidrasi dengan menggunakan alkohol bertingkat dari konsentrasi rendah sampai absolut, yaitu 70\%, 80\%, 90\%, dan absolut, masingmasing selama 1-2 jam. Lalu diinapkan 1 malam dalam larutan xylol (Nofrianinda, 2017).

Kemudian organ tersebut diclearing sampai jaringan menjadi transparan, dengan larutan xylol I selama 30 menit, dan II diinapkan selama 60 menit di dalam oven. Selanjutnya diinfiltrasi di dalam oven dengan temperatur $56{ }^{\circ} \mathrm{C}$, secara berturut-turut dimasukkan ke dalam parafin murni I, II, dan III masing-masing selama satu jam. Dilanjutkan dengan proses penanaman ke dalam kotak persegi empat yang telah diisi dengan parafin cair, lalu dimasukkan ke dalam lemari pendingin, dan diinapkan 1 malam agar parafin membeku. Setelah parafin tersebut membeku dikeluarkan dari kotak, dirapikan, ditempelkan pada holder, dan dipasangkan pada mikrotom untuk diiris dengan ketebalan enam mikron. Kemudian dilakukan proses penempelan, dimana pita irisan dimasukkan ke dalam air hangat, lalu diambil dengan gelas benda. Irisan ditempelkan pada gelas benda yang diletakkan di atas hot plate, dan dibiarkan mengering. Selanjutnya dideparafinasi dengan xylol sampai bebas dari parafin. Lalu dilakukan dealkoholisasi dengan memasukkan preparat tersebut ke dalam alkohol bertingkat, yaitu absolut, 80\%, 70\%, 50\%, 30\%, kemudian dicelupkan ke dalam akuades sebanyak 3-4 kali celupan. Selanjutnya dilakukan pewarnaan dengan menggunakan Hematoxylin-Erlich 3 menit, lalu mencuci dengan air mengalir lebih kurang 10 menit, dan dicelupkan ke dalam akuades, serta dimasukkan sebentar ke 
alkohol 30\%, 50\%, dan 70\%. Lalu dimasukkan ke dalam larutan pewarna eosin selama 3 menit. Kemudian berturutturut dimasukkan sebentar ke dalam alkohol 70\%, 80\%, dan absolut, lalu dikeringkan dengan kertas pengisap. Kemudian preparat dimasukkan ke dalam xylol selama satu malam. Selanjutnya ditutup dengan Canada balsam, dan diberi label. Lalu mengamati preparat di mikroskop (Nofrianinda, 2017).
HASIL DAN PEMBAHASAN

Berdasarkan hasil penelitian diperoleh preparat sayatan ovarium mencit untuk mengetahui gambaran histologis yang meliputi jumlah dan diameter folikel primer, sekunder, De Graff, korpus luteum, dan atretik dengan variasi ukuran untuk setiap preparat. Data tersebut disajikan di Tabel 1.

Tabel 1. Rataan Data Histologis Berupa Jumlah Folikel Primer, Sekunder, De Graff, Korpus Luteum, dan Atretik, Diameter Folikel Primer, Sekunder, De Graff, Korpus Luteum, dan Atretik yang Diberi Perlakuan Ekstrak Daun Andaliman selama 9 Hari

\begin{tabular}{|c|c|c|c|c|c|c|c|c|c|c|}
\hline \multirow{3}{*}{$\begin{array}{c}\text { Perlak } \\
\text { uan }\end{array}$} & \multicolumn{10}{|c|}{ Parameter } \\
\hline & \multicolumn{2}{|c|}{ Folikel Primer } & \multicolumn{2}{|c|}{ Folikel Sekunder } & \multicolumn{2}{|c|}{ Folikel De Graff } & \multicolumn{2}{|c|}{ Korpus Luteum } & \multicolumn{2}{|c|}{ Folikel Atretik } \\
\hline & $\begin{array}{l}\text { Jumlah } \\
\text { (buah) }\end{array}$ & $\begin{array}{c}\text { Diameter } \\
(\mathrm{mm})\end{array}$ & $\begin{array}{l}\text { Jumlah } \\
\text { (buah) }\end{array}$ & $\begin{array}{c}\text { Diameter } \\
(\mathrm{mm})\end{array}$ & $\begin{array}{l}\text { Jumlah } \\
\text { (buah) }\end{array}$ & $\begin{array}{c}\text { Diameter } \\
(\mathbf{m m})\end{array}$ & $\begin{array}{l}\text { Jumlah } \\
\text { (buah) }\end{array}$ & $\begin{array}{c}\text { Diameter } \\
\text { (mm) }\end{array}$ & $\begin{array}{l}\text { Jumlah } \\
\text { (buah) }\end{array}$ & $\begin{array}{c}\text { Diameter } \\
(\mathrm{mm})\end{array}$ \\
\hline P0 & 5,30 & 0,297 & 5,50 & $0,847 \mathrm{E}$ & 4,5 & 1,833 & $4,70 \mathrm{bB}$ & 2,708 & 4,70 & $\begin{array}{l}1,660 \\
a b A B\end{array}$ \\
\hline P1 & 2,17 & 0,322 & 2,70 & $1,295 \mathrm{aA}$ & 2,0 & 2,007 & $4,5 \mathrm{bB}$ & 2,942 & 2,50 & $1,900 \mathrm{Aa}$ \\
\hline P2 & 4,17 & 0,425 & 5,50 & $\begin{array}{l}0,992 \\
\text { cdeCDE }\end{array}$ & 4,0 & 1,383 & 8,17 aA & 2,592 & 4,83 & $\begin{array}{l}1,285 \\
\text { bcAB }\end{array}$ \\
\hline P3 & 2,50 & 0,393 & 5,50 & $1,068 \mathrm{cBC}$ & 3,3 & 1,873 & $5,83 \mathrm{bAB}$ & 2,838 & 3,70 & $1,107 \mathrm{bcB}$ \\
\hline P4 & 2,17 & 0,283 & 8,50 & $1,037 \mathrm{cdCD}$ & 2,5 & 1,547 & $5,17 \mathrm{bB}$ & 2,508 & 4,17 & $\begin{array}{l}1,133 \\
\text { bcAB }\end{array}$ \\
\hline P5 & 4,17 & 0,343 & 4,17 & $1,202 \mathrm{abAB}$ & 3,3 & 2,015 & $5,17 \mathrm{Bb}$ & 2,375 & 4,70 & $1,070 \mathrm{cB}$ \\
\hline
\end{tabular}

Keterangan : Angka-angka yang diikuti huruf yang sama pada kolom yang sama pada masing-masing perlakuan tidak berbeda nyata pada taraf 5\% (huruf kecil) dan tidak berbeda sangat nyata pada taraf 1\% (huruf besar) menurut uji Duncan Multiple Range Test (DnMRT). Dimana P0 : Kontrol akuades dengan dosis $0 \mathrm{~g} / 100 \mathrm{ml}$ akuades, P1 : Perlakuan dengan dosis 0,25 g/100 ml akuades, P2 : Perlakuan dengan dosis 0,5 g/100 ml akuades, P3 : Perlakuan dengan dosis $1,0 \mathrm{~g} / 100 \mathrm{ml}$ akuades, P4 : Perlakuan dengan dosis 2,0 g/100 ml akuades, P5 : Perlakuan dengan dosis 4,0 g/100 ml akuades.

Berdasarkan hasil penelitian acanthopodium DC.). data tersebut diperoleh kandungan zat kimia ekstrak disajikan di Tabel 2. etanol daun andaliman (Zanthoxylum

Tabel 2. Hasil Uji Kandungan Kimia Ekstrak Daun Andaliman

\begin{tabular}{cc}
\hline Zat & Hasil \\
\hline Fenolik & Negatif $(-)$ \\
Flavonoid & Negatif $(-)$ \\
Alkaloid & Positif $(++)$ \\
Steroid & Positif $(++)$ \\
Saponin & Positif $(+)$
\end{tabular}

Keterangan : $(-)$ : tidak ditemukan ; $(+)$ : ditemukan dalam kandungan rendah $(++)$ : ditemukan dalam kandungan tinggi 
Hasil pemberian ekstrak daun lahir akan berbeda pada setiap individu andaliman selama 9 hari (Tabel 1, Gambar akibat perubahan fisiologis dan hormonal 3) memperlihatkan adanya pengaruh sehingga menyebabkan adanya folikel terhadap jumlah folikel primer, yaitu atretik yang terbentuk (Al-Waeli, 2011). menunjukkan penurunan jumlah pada Selanjutnya dijelaskan bahwa kondisi kelompok perlakuan bila membandingkan fisiologis dan hormonal tersebut sangat dengan kontrol. Tetapi pada masing- dipengaruhi oleh faktor lingkungan, masing kelompok menunjukkan seperti cahaya, suhu dan kualitas penurunan jumlah yang berfluktuasi makanan, berpengaruh terhadap kondisi seiring dengan pertambahan konsentrasi mencit secara keseluruhan (Sianturi, perlakuan. Perbedaan jumlah folikel 2006). Faktor-faktor tersebut dapat primer yang berfluktuasi ini kemungkinan mempengaruhi kemampuan mencit disebabkan karena faktor internal pada mencapai potensi genetik untuk tumbuh, masing-masing mencit. Diameter folikel berbiak dan lain-lain, keadaan ini primer mencit menunjukkan hasil yang kaitannya dengan kondisi ovarium. Oleh meningkat bila membandingkan pada karena itu faktor makanan hewan yang kelompok perlakuan dengan kontrol. Dan diberikan dalam percobaan biomedis pada masing-masing kelompok perlakuan mempunyai pengaruh nyata pada kualitas menunjukkan penurunan diameter folikel hasil percobaan. Folikel primer adalah primer mencit seiring dengan folikel pada ovarium yang terdiri atas pertambahan dosis perlakuan. sebuah ovum imatur yang diliputi oleh

Faktor internal, seperti hormonal selapis sel gepeng (Kartiarso, 2007). Ovum dan fisiologis sangat mempengaruhi imatur atau oosit primer adalah berupa sel pertumbuhan folikel, walaupun lonjong dengan inti besar vesicular dan sebenarnya jumlah folikel primer sudah sebuah anak inti yang jelas. tetap dari masa embrional, tetapi setelah 


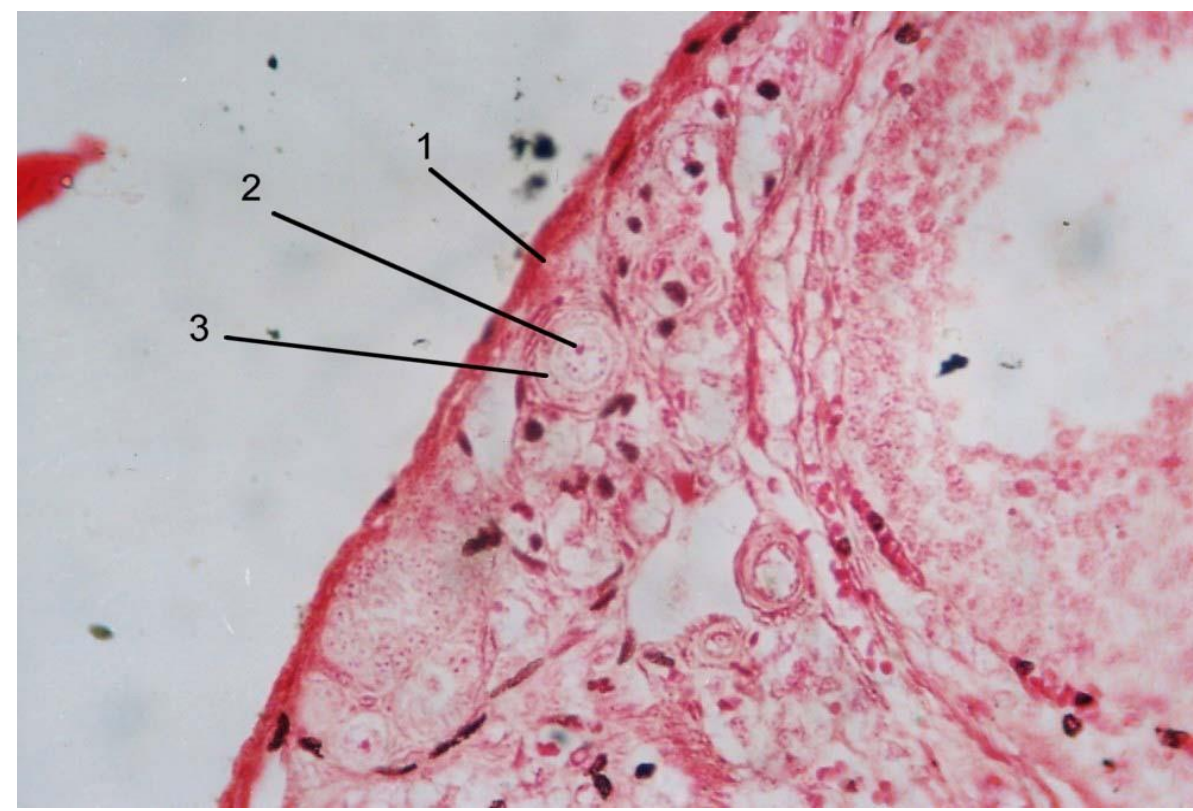

Gambar 3. Preparat sayatan pada ovarium mencit (Mus musculus L.) dengan perbesaran 400x : 1. Folikel primer, 2. Oosit, 3. Sel folikel

Dari pemberian ekstrak daun ovarium, terutama folikel sekunder andaliman selama 9 hari (Tabel 1, Gambar ovarium (Guyton, 2011; Malarkey, 2005). 4) memperlihatkan adanya pengaruh Proliferasi adalah pembelahan diri secara terhadap jumlah folikel sekunder, yaitu aktif (Rumanta, 2019). Folikel sekunder menunjukkan hasil yang meningkat pada kelompok perlakuan bila membandingkan dengan kontrol. Sedangkan pada diameter folikel sekunder, menunjukkan adalah folikel yang berkembang pesat yang terjadi setelah pubertas ditandai oleh pertumbuhan dan diferensiasi sel telur, peningkatan bila membandingkan dengan kontrol. Tetapi pada masing-masing kelompok perlakuan menunjukkan hasil yang berfluktuasi seiring dengan pertambahan dosis perlakuan. Perbedaan jumlah dan diameter folikel sekunder yang berfluktuasi ini kemungkinan disebabkan karena kandungan zat steroid dalam ekstrak daun andaliman tergolong tinggi. Zat steroid dapat meningkatkan proliferasi proliferasi sel folikel dan perkembangan lapisan dari jaringan stroma di sekitarnya (Kartiarso, 2007). Pertambahan ukuran folikel kemudian membentuk membran refraktil yang disebut zona pelusida yang mengelilingi ovum. Sedangkan folikel atretik adalah folikel ovarium yang mengalami pengisutan yang tidak berkembang menjadi matang secara normal yang akan terovulasi, tampaknya dimulai dari dalam ovum. dan pertumbuhan sel-sel folikel pada 


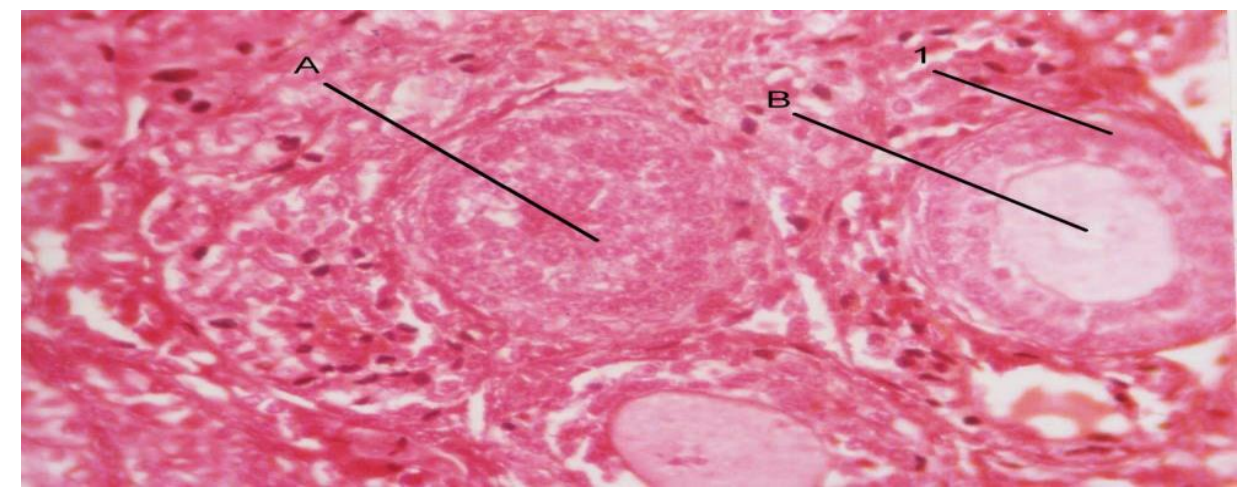

Gambar 4. Preparat sayatan pada ovarium mencit (Mus musculus L.) dengan perbesaran 400x : A.

Folikel Atretik dan B. Folikel Sekunder (Oosit) ; 1. Sel Folikel, 2. Zona pelusida

Folikel De Graff mencit yang yang diperlakukan, karena zat alkaloid didapatkan (Tabel 1, Gambar 5) mengandung toksik, sedangkan memperlihatkan adanya pengaruh kemampuan menghemolisis darah dimiliki terhadap jumlah folikel De Graff, yaitu oleh saponin (Hasibuan, 2017). Diameter cenderung menunjukkan penurunan folikel De Graff mencit menunjukkan hasil jumlah pada seluruh kelompok perlakuan, yang meningkat bila membandingkan bila membandingkan dengan kontrol. pada kelompok perlakuan dengan kontrol. Penurunan jumlah folikel De Graff yang Terjadinya fluktuasi dari diameter folikel berfluktuasi ini kemungkinan disebabkan De Graff kaitannya dengan jumlah folikel karena dosis dan volume zat alkaloid yang De Graff (Guyton, 2011; Malarkey, 2005), digunakan sebagai toksik dan tegangan apabila jumlah folikel De Graff bertambah, permukaan cairan tubuh yang dapat maka diameter folikel De Graffnya akan diturunkan oleh saponin dan menurun atau kecil. Keadaan ini menghemolisis sel darah. Zat alkaloid dan disebabkan karena terhambatnya saponin dapat menurunkan jumlah folikel pertumbuhan folikel yang satu akibat De Graff, keadaan ini sangat tergantung terjadinya pertumbuhan folikel yang lain. kepada kondisi fisik dan fisiologis hewan

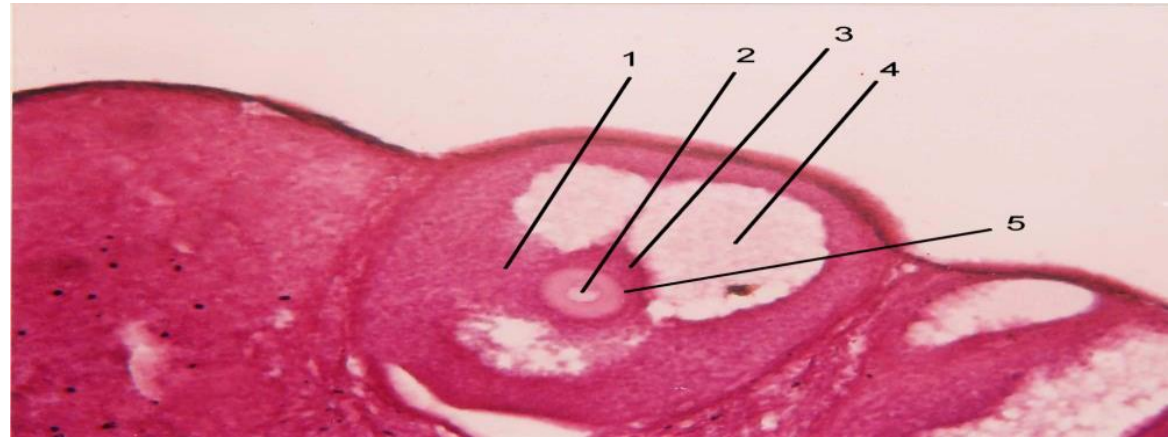

Gambar 5. Folikel De Graff pada ovarium mencit (Mus musculus L.) dengan perbesaran 100x : 1. Kumulus ooforus, 2. Oosit, 3. Korona radiata, 4. Rongga antrum dengan liquor folliculi, 5. Zona pelusida, 6. Sel granulosa, 7. Sel teka folikel 
Dari hasil pemberian ekstrak daun andaliman selama 9 hari (Tabel 1, Gambar 6) memperlihatkan adanya pengaruh terhadap jumlah korpus luteum, yaitu cenderung menunjukkan peningkatan bila membandingkan dengan kontrol. Dan secara statistik ditunjukkan hasil yang berbeda sangat nyata. Tetapi pada masingmasing kelompok perlakuan menunjukkan hasil yang berfluktuasi seiring dengan pertambahan dosis perlakuan. Perbedaan jumlah korpus luteum yang berfluktuasi ini kemungkinan disebabkan karena dosis dan volume zat steroid yang diberikan yang terkandung dalam ekstrak daun andaliman. Peningkatan jumlah korpus luteum pada penelitian ini kemungkinan disebabkan karena zat steroid yang dapat meningkatkan proliferasi pertumbuhan sel-sel folikel pada ovarium (Guyton, 2011; Malarkey, 2005). Selain itu juga karena salah satu hormon steroid yaitu progesteron mempercepat pematangan folikel De Graff sehingga mempercepat ovulasi yang akhirnya akan membentuk korpus luteum. Diameter korpus luteum mencit menunjukkan hasil yang menurun bila membandingkan pada kelompok perlakuan dengan kontrol. Dan pada masing-masing kelompok perlakuan menunjukkan penurunan diameter korpus luteum mencit seiring dengan pertambahan dosis perlakuan. Korpus luteum adalah dinding kempis dan berlipat-lipat sesudah ovulasi, yang berubah menjadi sebuah kelenjar sementara untuk menghasilkan hormon progesteron (Saragih \& Arsita, 2019).

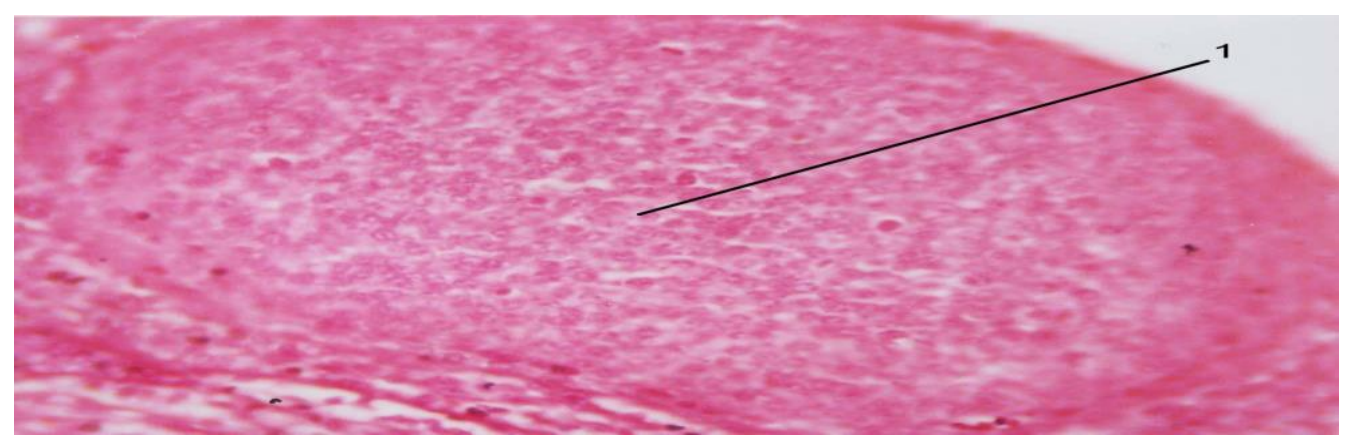

Gambar 6. Korpus Luteum pada ovarium mencit (Mus musculus L.) dengan perbesaran 400x :

\section{Sel Lutein}

Pada Tabel 1. (Gambar 4) perlakuan dengan kontrol. Tetapi pada memperlihatkan adanya pengaruh masing-masing kelompok perlakuan terhadap jumlah folikel atretik mencit, menunjukkan hasil yang berfluktuasi yaitu menunjukkan penurunan bila seiring dengan pertambahan dosis membandingkan dengan kontrol. perlakuan. Perbedaan jumlah dan Sedangkan pada diameter folikel atretik diameter folikel atretik yang berfluktuasi mencit menunjukkan penurunan bila ini kemungkinan disebabkan karena dosis membandingkan pada kelompok dan volume zat alkaloid yang digunakan 
sebagai toksik, dan tegangan permukaan cairan tubuh yang dapat diturunkan oleh saponin dan dapat menghemolisa darah, yang terkandung dalam ekstrak daun andaliman (Hasibuan, 2017).

Daur ovarium sendiri digiatkan dan diatur oleh gonadotropin oleh hipofisis lobus anterior yang menggetahkannya. Gonadotropin merupakan FSH dan LH, mengelola pematangan folikel dan pembentukan korpus luteum (Amin, 2012).

Di dalam ovarium terjadi rentengan perubahan bangunan, yaitu tumbuh kembang folikel, ovulasi dan pembentukan korpus luteum. Oleh karenanya kadar kedua hormon tersebut dalam keadaan normal memperlihatkan irama daur yang teratur. Estrogen tinggi pada masa praovulasi dan pembentukan progesteron meningkatkan cepat selama pembentukan korpus luteum dari folikel yang telah meletup dan bertahan tinggi kadarnya sampai korpus luteum mengisut. Kegiatan pergetahan ovarium merupakan sebab terjadinya perubahan berirama pada alat reproduksi terutama mukosa rahim (Amin, 2012).

Dari Tabel 2. terlihat bahwa mendapatkan kandungan kimia ekstrak daun andaliman yang paling tinggi adalah dari zat alkaloid dan steroid, sedangkan saponin dalam kandungan rendah.
Diantara 3 macam zat kimia ekstrak daun andaliman yang didapatkan tersebut, kemungkinan menurunnya berat dan diameter ovarium disebabkan oleh alkaloid dan steroid yang memiliki kandungan tinggi yang terdapat di ekstrak daun andaliman yang diperlakukan. Alkaloid dan saponin umum digunakan dalam obat-obatan. Alkaloid bersifat racun, sedangkan zat saponin penggunaannya untuk diturunkannya tegangan permukaan cairan tubuh dan dapat menghemolisis darah (Hasibuan, 2017). Karena pecahnya membran sel darah merah yang menyebabkan hemolisis adalah keluarnya isi sel dari dalam menuju ke cairan sekelilingnya (Rumanta, 2019). Sedangkan tegangan permukaan adalah tekanan membran sel akibat akumulasi air di dalamnya.

Senyawa alkaloid yaitu suatu golongan organik yang banyak ditemukan di alam, dan berasal dari tumbuhan. Alkaloid mengandung 1 atom nitrogen yang bersifat basa, dan merupakan cincin heterosiklik. (Hasibuan, 2017). Selanjutnya dijelaskan bahwa mempunyai keaktifan fisiologis dan efek phisikologis tertentu, ada yang terkenal sangat beracun dan berguna dalam pengobatan, misalnya quinin, morfin, dan striknin. Tanaman yang digunakan manusia terkandung alkaloid di minuman seperti teh, obat-obatan 
kedokteran, dan racun. Menemukan alkaloid yang pertama secara kimia yaitu dari getah kering Opium (Papaver sammiferum), menggunakan dalam obatobatan dan sebagai analgesik maupun narkotik.

Senyawa steroid merupakan turunan dari triterpenoid dan strukturnya yaitu kelipatan dari 6 unit isoprena yang terdapat pada tanaman (Hasibuan, 2017). Kegunaan steroid yang penting di antaranya secara fisiologis merupakan senyawa aktif yang terlibat di kehidupan dapat mempengaruhi sistem hormonal, seperti adrenal, dan seks (Widyawati, 2006). Lintasan biosintesis sebelum menjadi hormon steroid berasal dari asam asetat dan berubah menjadi asam mevalonat (Jarvis, 2019).

Senyawa saponin adalah golongan steroid glikosida, tegangan permukaan cairan tubuh dapat diturunkan dan menghemolisa darah, menghidrolisisnya dihasilkan aglikon dan glikosida, yang merupakan triterpenoid, sterol, steroid, dan saponin (Hasibuan, 2017).

Tanaman andaliman termasuk tanaman perdu yang tersebar di beberapa negara, di antaranya adalah di India Timur, Nepal, Pakistan Timur, Myanmar, Thailand, Cina, dan Sumatera Utara. Di negara Jepang terdapat rempah sansho (Zanthoxylum piperitum DC.) bentuk dan aroma buahnya yang dimiliki serupa tanaman andaliman, mengenal rempah Zanthoxylum simulans dan Zanthoxylum bungeanum Maxim. Aroma dan kandungan komponen volatil yang dimiliki serupa tanaman andaliman. Hanya saja saat ini belum diperoleh laporan rempah tersebut juga memberikan sensasi trigerminal seperti halnya pada tanaman andaliman (Saragih, 2019). Selanjutnya dijelaskan bahwa tanaman andaliman merupakan tumbuhan liar dan di Sumatera Utara terdapat pada daerah dengan ketinggian di atas $1500 \mathrm{mdpl}$.

Penelitian terdahulu yang berhubungan dengan ekstrak daun andaliman yaitu bahwa kandungan terpenoid tanaman andaliman mempunyai aktivitas antioksidan dan antimikroorganisme, mempunyai efek imunostimulan. Saat ini tanaman andaliman menjadi perhatian untuk dapat dimanfaatkan sebagai sumber aromatik dan minyak esensial. Karena senyawa aromatik dikandung buah tanaman andaliman dengan rasa pedas dan getir yang khas (Siregar, 2003).

\section{SIMPULAN}

Hasil penelitian yang telah dilakukan dapat mengambil kesimpulan sebagai berikut : (1) Setelah dilakukan uji kimia dengan menggunakan metode fitokimia, dapat diketahui bahwa ekstrak daun andaliman mengandung zat kimia 
berupa alkaloid dan steroid dalam jumlah yang cukup banyak, serta saponin dalam jumlah yang sedikit, (2) Pemberian ekstrak daun andaliman selama perlakuan 9 hari terhadap jumlah folikel primer, sekunder, De Graff, dan atretik, serta diameter folikel primer, De Graff, dan korpus luteum ditunjukkan hasil yang tidak berbeda nyata antara kelompok mencit perlakuan dan kontrol,

Pemberian perlakuan terhadap jumlah korpus luteum, diameter folikel sekunder ditunjukkan hasil yang berbeda sangat nyata yang meningkat antara kelompok mencit perlakuan dan kontrol. Tetapi pemberian perlakuan terhadap diameter folikel atretik menunjukkan hasil yang berbeda nyata yang menurun antara kelompok mencit perlakuan dan kontrol.

\section{DAFTAR PUSTAKA}

Al-waeli, A. M. (2011). group was given Tribuls terrestris , the 2. 24(4).

Amin, N. F., \& Shamim, K. M. (2012). Trends in the Presentation of Cell Biology and Histology in Contemporary Histology Books as Revealed in Their 'Preface's. Bangabandhu Sheikh Mujib Medical University Journal, 5(1). https://doi.org/10.3329/bsmmuj.v5i1.11017

Hall, J. E. (1392). Guyton and Hall Textbook of medical Physiology. In Saunders Elsevier (Twelfth).

Hasibuan, R., \& Dimenta, R. H. (2017). Kajian Kandungan Fitokimia Dari Ekstrak Haramonting (Rhodomytus tomentosa) sebagai. Gambar 1.

Jarvis, G. E., \& Saunders, P. (2017). embryo mortality in natural human reproduction:
What the data say [ version 2 ; referees : 1 approved , 2 approved with reservations ] Referee

Status :o. https://doi.org/10.12688/fioooresearch.8937 .1

Malarkey, D. E., Johnson, K., Ryan, L., Boorman, G., \& Maronpot, R. R. (2005). New Insights into Functional Aspects of Liver Morphology. Toxicologic Pathology, 33(1), 27-34.

https://doi.org/10.108o/01926230590881826

Nofrianinda, V., Yulianti, F., \& Agustina, E. (2018). Pertumbuhan Planlet Stroberi (Fragaria ananassa D) Var. Dorit pada Beberapa Variasi Media Modifikasi In Vitro di Balai Penelitian Jeruk dan Buah Subtropika (BALITJESTRO). Biotropic: The Journal of Tropical Biology, 1(1), 32-41. https://doi.org/10.2908o/biotropic.2017.1.1.3 2-41

Pranowo, W. S., Supangat, A., \& Ningsih, N. S. (2005). Modelling Of Nitrogen Compounds Distribution In Jepara Waters, Northern Coast Of Central Java Indonesia By:XII(2), 1-8.

Saragih, D. E., \& Arsita, E. V. (2019). The phytochemical content of Zanthoxylum acanthopodium and its potential as a medicinal plant in the regions of Toba Samosir and North Tapanuli, North Sumatra. Prosiding Seminar Nasional Masyarakat Biodiversitas Indonesia, 5(1), 7176.

https://doi.org/10.13057/psnmbi/mo50114

Siregar, B. L. (2003). Andaliman (Zanthoxylum acanthopodium DC.) in North Sumatra: Description and Germination. Hayati, 10(1), 38-41.

Soewolo. (2000). Pengantar Fisiologi Hewan. 1-36. Widyawati, G., Solichatun, S., \& Marliyana, S. D. (2006). The effect of naftalene acetic acid (NAA) on growth and essential oil contents of jasmine callus (Jasminum sambac (L.) Ait.). Biofarmasi Journal of Natural Product Biochemistry, 4(2), 41-44. https://doi.org/10.13057/biofar/fo40201

Wiryawan, K. G. (2006). Kajian Penambahan Ragi Tape pada Pakan terhadap Konsumsi, Pertambahan Bobot Badan, Rasio Konversi Pakan, dan Mortalitas Tikus (Rattus norvegicus). Media Peternakan, 29(3), 155161.

Year, I. I. (n.d.). Taxonomy of Angiosperm And Biodiversity. 